\title{
MODEL PENGEMBANGAN BUDAYA RELEGIUS DI MADARASAH IBTIDAIYAH DALAM PENGUATAN KARAKTER SISWA
}

\author{
Luluk Sultoniyah \\ Pascasarjana IAIN Jember \\ luluksultoniyah@gmail.com
}

\author{
Ahmad Royani \\ Progam Studi Manajemen Pendidikan Islam IAIN Jember \\ royanpuritanjung@gmail.com
}

\begin{abstract}
Moral decadence phenomenon among teenagers includes college student. Lately, it has disturbed many parties. The phenomenon could seen from juvenile deliquency, drug, and free relationship. Higher educational institution that shoud be moral development center and students moral, even in some cases being a moral decadence transit. Therefore, educational institution is not only expected as a place to get knowledge, but also could give enough stock in educating strong student morals to face globalization era. The development of religious culture in MI Al-Barokah An-Nur Ajung Jember is carried out by instilling systematic behavior or manners in practicing their religions, so that they have good personality, character, noble morality, and responsibility, both their relationship with Allah, with human beings and with the environment. therefore, the values developed at MI Al-Barokah An-Nur were emphasizing morality, achievement, discipline and environmental culture.
\end{abstract}

\section{Kata Kunci: Budaya relegius, Karakter Siswa}

\begin{abstract}
Abstrak
Fenomena dekadensi moral di kalangan remaja termasuk mahasiswa. Belakangan ini hal itu meresahkan banyak pihak. Fenomena tersebut terlihat dari kenakalan remaja, narkoba, dan hubungan bebas. Perguruan tinggi yang seharusnya menjadi pusat pengembangan moral dan moral siswa, bahkan dalam beberapa kasus menjadi transit dekadensi moral. Oleh karena itu, lembaga pendidikan tidak hanya diharapkan sebagai
\end{abstract}


tempat menimba ilmu, tetapi juga dapat memberikan bekal yang cukup dalam mendidik akhlak siswa yang kuat untuk menghadapi era globalisasi. Pengembangan budaya keagamaan di MI Al-Barokah An-Nur Ajung Jember dilakukan dengan menanamkan perilaku atau tata krama yang sistematis dalam mengamalkan agamanya, sehingga memiliki kepribadian, akhlak, akhlak yang mulia, dan tanggung jawab yang baik, baik hubungannya dengan Allah, maupun hubungan mereka dengan Allah. dengan manusia dan dengan lingkungan. Oleh karena itu nilai-nilai yang dikembangkan di MI Al-Barokah An-Nur adalah mengutamakan moralitas, prestasi, disiplin dan budaya lingkungan.

\section{Kata Kunci : Budaya relegius, Karakter Siswa}

\section{Pendahuluan}

Aspek moralitas, tata nilai dan religiusitas selayaknya menjadi prioritas untuk di internalisasi kepada siswa, hal ini sejalan dengan undang-undang sistem pendidikan nasional tahun 2003, bab 1, pasal 1, ayat 1 dan ayat 3 yang menyatakan bahwa :

"Pendidikan adalah usaha sadar dan terencana untuk mewujudkan suasana belajar dan proses pembelajaran agar peserta didik secara aktif mengembangkan potensi dirinya untuk memiliki kekuatan spiritual, keagamaan, pengendalian diri, kepribadian, kecerdasan, akhlak mulia, serta keterampilan yang diperlukan dirinya, masyarakat, bangsa, dan negara. Tujuan pendidikan nasional adalah mengembangkan potensi peserta didik agar menjadi manusia yang beriman dan bertakwa kepada Tuhan Yang Maha Esa, berakhlak mulia, sehat, berilmu, cakap, kreatif, mandiri, dan menjadi warga negara yang demokratis serta bertanggung jawab".1

Pengembangan budaya religius sebagai bagian dari

1 Tim Diknas RI, Undang-undang nomor 20 tahun 2003 tentang Sisdiknas, (Semarang ; Pustaka Offset, 2004), 6 
Vol. 12, No. 1, April 2019

p-ISSN:2086 -0749

e-ISSN:2654-4784

pembentukan karakter bangsa menjadi urgen, karena tidak ada satupun negara yang sukses meraih pembangunan bila moralitasnya rendah. Masyarakat yang kokoh adalah mereka yang mempunyai pondasi moral dan etika yang kokoh sehingga mendorong timbulnya semangat kemandirian, kejujuran, kerja keras, tanggung jawab keluarga dan sosial. AlMawardi menyebutkan bahwa dekadensi moral merupakan hal paling cepat dalam menghancurkan bangsa dan sendi-sendinya ${ }^{2}$. Gustave Le Bon juga menyebutkan bahwa dengan kemuliaan akhlak suatu bangsa akan menjadi terhormat, sebaliknya sebuah bangsa akan ambruk bila akhlaknya rusak. $^{3}$

2 Abul Hasan Al-Mawardi, Adab addunya wa-addin (Kairo: Darr al-ilm, tt), 115

3 Gustave Le Bon, As-sunan anNafsiah Li tathowwur al-Umam.. Terj. Abu Bakar Ibn Zuhayl, (Marocco : universitas al-Qurawiyien,1997), 172
Peran guru dalam membentuk karakter peserta didik tidak cukup hanya dengan mengajar peserta didik membaca, menulis, dan berhitung, kemudian lulus ujian, serta nantinya mendapatkan pekerjaan. Pendidik juga perlu mengembangkan kegiatan yang mengandung nilai-nilai keagamaan, misalnya dengan membudayakan salam(sungkem) dan bacaan sholat sebelum kegiatan pembelajaran dimulai. Pembiasaan salam dan bacaan sholat yang dilakukan secara rutin sebelum kegiatan pembelajaran dimulai merupakan salah satu cara dalam mengembangkan karakter religius dan disiplin peserta didik.

Berkaitan dengan hal tersebut, sebagai lembaga pendidikan berbasis Islam, madrasah memegang peran penting dalam proses pembentukan kepribadian peserta didik, karena 


\section{Luluk Sultoniyah, Ahmad Royani}

melalui pendidikan madrasah ini para orang tua berharap agar anakanaknya memiliki dua kemampuan sekaligus, tidak hanya ilmu pengetahuan dan teknologi, tetapi juga memiliki iman dan taqwa. Spirit pengembangan budaya religius bukan sekedar memberi pengetahuan tentang keagamaan, melainkan yang utama adalah membiasakan anak taat dan patuh menjalankan ibadah dan berprilaku sesuai dengan norma-norma yang telah ditetapkan dalam agama masingmasing.

Muhaimin mengungkapkan b ahwa untuk mendidik karakter dan nilai-nilai yang baik, termasuk didalamnya nilai keimanan kepada Tuhan yang Maha Esa diperlukan pembinaan terpadu antara tiga dimensi nilai keimanan bagi peserta didik, yakni pengembangan moral knowing, moralfeeling dan moralaction, dari proses ter- sebut secara berurutan tercipta suasana religius di madrasah. ${ }^{4}$

Madrasah Ibtidaiyah AlBarokah An-Nur Ajung Jember merupakan lembaga yang terletak diwilayah pedesaan tepatnya di desa Ajung kecamatan Ajung. Memiliki visi besa "Berakhlakul Karimah, Berprestasi, Disiplin dan Berbudaya Lingkungan" tentunya meberikan dampak pada model strategi yang dilakukan oleh pengelola sekolah untuk bisa mengaplikasikan dalam kehidupan ataupun lingkungan madrasah. Selain itu misi besar yang ada pada lembaga ini adalah; 1) melaksanakan kegiatan keagamaan secara rutin dan terjadwal. 2) melaksanakan KBM dan bimbingan belajar belajar secara terjadwal, efektif dan efisien. 3) memotivasi dan melaksanakan pembinaan kompetensi bidang akademik dan non akademik. 4) mewujudkan

\footnotetext{
4 Muhaimin, Rekonstruksi Pendidikan Islam; dari Paradigma Pengembangan, Manajemen Kelembagaan, Kurikulum bingga Strategi Pembelajaran. Jakarta: Grafindo Persada.2009).68
} 
kesadaran prilaku berwawasan lingkungan. ${ }^{5}$

Untuk merealisasikan visi dan misi pendidikan MI Al-Barokah An-Nur Ajung Jember, maka pembinaan siswa dilakukan melalui proses pembinaan sikap dan prilaku sehari-hari di madrasah yang diharapkan dapat terwujudnya budayadan iklim relegius madrasah, yang pada akhirnya akan membentuk kepribadian siswa yang berkarakter akblaqul karimah. Pembiasaan dan tata prilaku yang dimaksud sebagai budaya madrasah yang berkarakter relegius.

Taufiq Hasyim menyebutkan pengembangan budaya religius pada perserta didik di madrasah dapat dilakukan dengan menanamkan perilaku atau tatakrama yang tersistematis dalam pengamalan agamanya masing-masing sehingga ter-

${ }^{5}$ Dokumetasi, Madrasah Ibtidaiyah Al-Barokah An-Nur Ajung Jember 2019 bentuk kepribadian, karakter, sikap dan moralitas yang mulia, berjiwa luhur, dan bertanggung jawab, baik hubungannya dengan Allah swt, dengan sesama manusia maupun dengan lingkungan alam sekitar. ${ }^{6}$

Mengingat strategisnya pengembangan budaya religius sebagai bagian dari pembentukan karakter bangsa dan berangkat dari berbagai keunikan empris mengenai strategi pengembangan budaya religius di madrasah Ibtidaiyah AlBarokah An-Nur Ajung Jember,maka tulisan ini penting untuk disajikan sebagai wahana atau model pengembanagan budaya relegius di madrasah.

\section{Metodologi Penelitian}

Jenis penelitian ini adalah penelitian lapangan (field research) dengan rancangan studi kasus, yakni

\footnotetext{
6 Taufiq Hasyim, Budaya Relegius di lembaga Pendidikan Islam. (Bandung: Cita Pustaka Media, 2008 ), 46
} 


\section{Luluk Sultoniyah, Ahmad Royani}

eksplorasi terhadap suatu latar ( $a$ detailed examination of one setting), atau satu peristiwa tertentu (one particular event), atau satu subjek (one single subject) atau satu tempat penyimpanan dokumen (one single depository of document) dengan cara menginvestigasi secara eksploratif, deskriptif dan utuh (wholeness) fenomena sementara dalam konteks kehidupan nyata (real live context). Karena pendekatan yang digunakan kualitatif maka dalam konteks ini peneliti lebih banyak mendeskripsikan dan menganalisis data hasil penelitian terkait dengan fokus penelitian yakni yakni pengembangan budaya religius di Madrasah Ibtidaiyah Al-Barokah An-Nur Ajung Jember.

\section{Temuan Penelitian dan}

\section{Pembahasan}

1. Strategi Pengembangan Budaya Religius di Madrasah

${ }^{7}$ Imron Arifin, Metode Penelitian Kualitatif (Malang, Kalimasada Press, 2009),77.
Ibtidaiyah Al-Barokah AnNur Ajung Jember

Pengembangan budaya agama di madrasah adalah sesuatu yang sangat urgen untuk dilakukan. Urgensi pengembangan budaya agama di sekolah adalah agar seluruh warga sekolah memperoleh kesempatan untuk dapat memiliki bahkan mewujudkan seluruh aspek keberagamaannya baik pasa aspek keyakinan (keimanan), praktik agama, pengalaman, pengetahuan agama, dan dimensi pengamalan keagamaan. Semua itu dapat diwujudkan melalui berbagai kegiatan keagamaan sebagai wahana dalam upaya menciptakan dan mengembangkan budaya religius di madrasah.

Madrasah Ibtidaiyah AlBarokah An-Nur Ajung Jember merupakan lembaga yang terletak diwilayah pedesaan tepatnya di desa Ajung kecamatan Ajung. Memiliki visi besa "Berakhlakul Karimah, Berprestasi, Disiplin dan Berbudaya 
Lingkungan" tentunya meberikan dampak pada model strategi yang dilakukan oleh pengelola sekolah untuk bisa menaplikasikan dalam kehidupan ataupun lingkungan madrasah. Tidak heran misi besar yang ada pada lembaga ini adalah; 1) Melaksanakan Kegiatan Keagamaan secara Rutin dan Terjadwal. 2) Melaksanakan KBM dan Bimbingan Belajar Belajar secara Terjadwal, Efektif dan Efisien. 3) Memotifasi dan Melaksanakan Pembinaan Kompetensi Bidang Akademik dan Non Akademik. 4) Mewujudkan kesadaran prilaku berwawasan lingkungan. ${ }^{8}$

Untuk merealisasikan visi dan misi pendidikan MI Al-Barokah An-Nur Ajung Jember, maka pembinaan siswa dilakukan melalui proses pembinaan sikap dan prilaku

${ }^{8}$ Dokumetasi, Madrasah Ibtidaiyah Al-Barokah An-Nur Ajung Jember 2019 sehari-hari di madrasah yang diharapkan dapat terwujudnya budaya Madrasah, yang pada akhirnya akan membentuk kepribadian siswa yang berkarakter akblaqul kekarimah. Pembiasaan dan tata prilaku yang dimaksud sebagai Budaya Madrasah yang berkarakter relegius.

Dalam skala yang lebih luas, budaya mutu pendidikan akan melibatkan stakeholders pendidikan seperti pemerintah, yayasan, kepala madrasah, dewan guru dan tenaga kependidikan serta komite madrasah. Oleh karena itu MI Al-Barokah An-Nur Ajung Jember merumuskan dalam tiga hal membangun budaya mutu di dunia pendidikan khususnya pengembangan budaya madrasah yaitu: Pertama, Institusional Building,maksudnya bahwa madrasah harus membangun institusi kelembagaan yang kuat dengan berorentasi dan berkomitmen pada mutu. Baik mutu masukan, proses 


\section{Luluk Sultoniyah, Ahmad Royani}

maupun lulusan yang setidaknya dalam 8 Standar Nasional Pendidikan. Kedua, Caracteristic Building, maksudnya adalah menciptakan karakter kepala madrasah, guru dan karyawan pada prilaku yang luhur, beradab yang mendukung pada mutu dan kualitas. Tidak didasarkan pada mahalnya sebuah lembaga pendidikan tetapi bagaimana meningkatkan akses dan meningkatkan mutu masyarakat pada layanan pendidikan. Ketiga, Image Building, jika langkah pertama dan kedua telah berjalan tentu image (kesan) bahwa madrasah yang kita kelola benar-benar mengutamakan kualitas/mutu. ${ }^{9}$

Hj. Tartimatus Sholehah, M.Pd. I yang merupakan kepala Madrasah Ibtidaiyah Al-Barokah An-Nur Ajung Jember dalam wawancara menyebutkan bahwa hal yang paling utama dan pertama da-

\footnotetext{
9 Nasir, Pengembangan Pendidikan Karakter di Lembaga Pendidikan : Studi Multikasus di SMUN O4 dan SMU AlHidayah Malang, (Malang, Disertasi UNM, 2018)
}

lam penanaman budaya relegius madrasah adalah suri tauladan. Tentunya suri tauladan tidak hanya meberikan contoh saja dari dewan guru. Tapi yang jauh lebih penting adalah memberikan dorongan kepada semua pihak baik siswa guru dan warga madrasah saling bahu membahu menerapkan budaya relegius dalam kehidupan persekolahan. ${ }^{10}$

Proses belajar mengajar merupakan aspek yang paling terpenting dalam strategi pengembanagan budaya relegius terutama dalam pembentukan karakter dan akhlak anak dengan pengembangan budaya religius madrasah yang rutin dilaksanakan di setiap hari dalam pembelajaran. Kegiatan ini diprogram secara baik, sehingga peserta didik mampu menerima dengan baik. Dalam kerangka ini pendidikan merupakan tanggung jawab bersama bukan hanya guru agama saja. Pendidikan agama

10 Tartimatus Sholehah, Wawancara 17 Maret 2019 
tidak hanya terbatas aspek pengetahuan semata, tetapi juga meliputi aspek pembentukan sikap, perilaku, dan pengalaman keagamaan. ${ }^{11}$

Dalam kesempatan yang sama Abdu Gafur yang merupakan guru olah raga juga menyampaikan bahwa dalam konteks strategi pengembangan budaya relegius di Madrasah Ibtidaiyah Al-Barokah An-Nur Ajung memerlukan sosok yang tegas dalam aplikasinya.

"dalam kontes kedisiplinan bu tartim sangat istiqomah, terutama dalam kontes penguatan sikap relegiusitas siswa. Dipagi hari bu tartim selalu memantau aktifitas kegiatan sbeleum masuk kelas yakni mebaca do'a dengan cara berbaris di depan kelas. Selain itu juga untuk membakar semangat madrasah dipagi hari selalu dibunyikan ayat ayat al'quran dan juga musik islami" ${ }^{12}$

Hal diatas juga dikuatkan dengan hasil obesrvasi peneliti terkait dengan strategi yang dilakukan madrasah dalam budaya relegius. Peneliti melihat secara lansung aktivitas yang dilakukan oleh dewan guru dalam penanaman budaya sehat dengan menjaga lingkungan. Terlihat seorang guru sedang memungut sampah yang ada dipelataran madrasah setelah itu diikuti oleh siswa lain. ${ }^{13}$

Ni'matul Ittihad, juga memberikan pandangan terkait dengan strategi madrasah dalam penanaman budaya relegius salah satunya adalah aspek suritauladan dari semua pihak, khususnya kepala

\footnotetext{
12 Abdul Gafur, Wawancara, 18 Maret 2019

13 Obeservasi Madrasah Ibtidaiyah Al-Barokah An-Nur Ajung Jember
} 


\section{Luluk Sultoniyah, Ahmad Royani}

madrasah dewan guru dan juga tenaga kependidikan ${ }^{14}$

Dalam kesempatan yang berbeda Cahyo Irwanto juga menjelaskan dalam wawancara;

"Yang dibutuhkan anak adalah perhatian terhadap akhlaknya. Ia akan tumbuh menurut apa yang dibiasakan oleh pendidikannya ketika kecil. Jika sejak kecil ia terbiasa marah, keras, tergesagesa, mudah mengikuti hawa nafsu, serampangan, tamak dan seterusnya, maka akan sulit baginya untuk memperbaiki dan menjauhi hal itu ketika dewasa. Perangai seperti ini akan menjadi sifat dan perilaku yang melekat pada dirinya. Jika ia tidak dibentengi betul dari hal itu, suatu saat nanti perangai itu akan muncul. Karena itu ketika menemukan orang yang akhlaknya menyimpang, hal itu disebabkan oleh pendidikan yang dilaluinya. ${ }^{15}$

2019

4 Abdul Gafur, Wawancara, 18 Maret

15 Cahyo Irwanto, Wawancara, 20 Maret 2019
Selain itu juga Strategi Pengembangan Budaya Religius di Madrasah Ibtidaiyah Al-Barokah An-Nur Ajung Jember yakni penciptaan suasana religius bagi peserta didik. Pencipatanaan suasana ini tentunya didukung dengan iklim organisasi madrasah. Tartimatus Sholehah menjelaskan menciptakan lingkungan lembaga pendidikan yang mendukung dan dapat menjadi laboratorium bagi penyampaian pendidikan agama. Lingkungan dalam konteks pendidikan memang memiliki peranan yang signifikan dalam pemahaman dan penanaman nilai. Suasana lingkungan lembaga pendidikan dapat menumbuhkan budaya religius (religius culture). Suasana lembaga pendidikan yang ideal semacam ini dapat membimbing peserta didik agar mempunyai akhlak mulia, perilaku jujur, disiplin, dan semangat sehingga akhirnya men- 
Vol. 12, No. 1, April 2019

p-ISSN:2086 -0749

e-ISSN:2654-4784

jadi dasar untuk meningkatkan kualitas dirinya. ${ }^{16}$

Olah karena itu, di madrasah, budaya religius dapat diciptakan dengan cara pengadaan peralatan peribadatan, seperti tempat shalat (masjid atau mushola), alat alat shalat, seperti mukena, peci, sajadah atau pengadaan Al-Quran. Di dalam ruangan kelas bisa ditempel kaligrafi, sehingga peserta didik dibiasakan selalu melihat sesuatu yang baik Cara lain ialah sebagai seorang guru selalu memberi contoh yang terbaik bagi peserta didiknya, misalnya selalu mengucapkan salam ketika hendak memulai atau mengakhiri pelajaran dan ketika bertemu, baik dengan guru maupun rekan sebayanya Kelima, memberikan kesempatan bagi peserta didik untuk mengek-

16 Obeservasi Madrasah Ibtidaiyah Al-Barokah An-Nur Ajung Jember spresikan diri, menumbuhkan bakat, minat, dan kreativitas pendidikan agama dalam keterampilan dan seni seperti membaca Al Qur'an dengan lagu (taghoni), membaca asmaul husna, adzan, tilawah, dan lain-lain $^{17}$

Strategi pengembangan budaya religius membutuhkan dukungan dan peran aktif dari berbagai pihak pelaksana maupun pemangku kebijakan seperti guru, siswa, orang tua, masyarakat, dan pemerintah. Jika semua elemen mendukung dan bersama-sama terlibat aktif dalam pelaksanaan budaya religius di madrasah sesuai dengan tugas pokok dan fungsinya masing-masing, maka keberadaan madrasah dengan budaya religius yang tertanam kuat dalam semua warga madrasah akan menjadi solusi akan kebutuhan masyarakat

\footnotetext{
17 Tartimatus Sholehah, Wawancara 17 Maret 2019
} 


\section{Luluk Sultoniyah, Ahmad Royani}

terhadap lembaga pendidikan yang mampu mendidik dan membentengi anak-anaknya dari pengaruh negatif perkembangan teknologi yang sangat maju.

Dalam konteks strategi pengemabangan Budaya Religius di Madrasah Ibtidaiyah Al-Barokah An-Nur Ajung Jember paling tidak menggunakan tiga model, yakni pengembangaan budaya relegius melalui proses belajar mengajar, strategi pengembanagan budaya relegisus melalaui suritauladan dan yang terahir strategi pengembanagan melalui penciptaaan iklim madrasah relegius.

2. Nilai-nilai budaya religius yang tumbuh di Madrasah Ibtidaiyah Al-Barokah AnNur Ajung Jember

Pembiasaan ini memiliki tujuan untuk menanamkan nilainilai relegiusitas yang diperoleh siswa dari hasil pembelajaran disekolah untuk diterapkan dalam perilaku siswa sehari-hari. Banyak hal bentuk pengamalan nilai-nilai religius yang bisa dilakukan di madrasah. Sebagai mana dijelaskan diatas Madrasah Ibtidaiyah Al-Barokah An-Nur Ajung Jember memiliki visi besa "Berakhlakul Karimah, Berprestasi, Disiplin dan Berbudaya Lingkungan". ${ }^{18}$

Secara umum nilai nilai di MI Al-Barokah An-Nur Ajung Jember sebagaimana dokumentasi sebagai berikut; 1) Kegiatan sekolah dilaksanakan pagi hari dengan 5 hari belajar dalam seminggu.2) Setiap pagi siswa dilepas pergi ke sekolah oleh kedua orang tua dengan iringan salam dan do'a. 3) Setiap hari belajar Al-Qur'an. 4) Setibanya di sekolah sudah disambut Ustadzustadzah, dengan budaya $5 \mathrm{~S}$ (Senyum, Sapa, Salam, Sopan, Santun). 5) Setiap hari siswa membiasakan shalat sunat dhuha dan shalat fardhu. 6) Menghafalkan dan membiasakan mengamalkan do'a amaliah harian. 7) Membuang sampah pada tempatnya dengan LiSA

${ }^{18}$ Dokumetasi, Madrasah Ibtidaiyah Al-Barokah An-Nur Ajung Jember 2019 
Vol. 12, No. 1, April 2019

p-ISSN:2086 -0749

e-ISSN:2654-4784

(lihat sampah ambil) 8) Datang tepat waktu atau kedisiplinan. 9) Antri ketika berwudhu dan jajan di kantin madrasah. 10) Berpakaian rapi dan sopan lengkap dengan atribut madrasah. 11) Berkata dan berbahasa yang baik dan santun. 12) Gemar membaca. 13) Memuji kebaikan dan keberhasilan teman. 14) Saling mengingatkan dan menolong dalam hal kebaikan. 15) Melakukan amalan yang tercermin dalam "Birrulwalidain" yakni: Berbakti kepada orang tua, Ikhlas dan rajin beramal, Ramah dalam bergaul, Ulet dalam mencapai cita-cita, Logis dalam berpikir, Amanah, dapat dipercaya, Lemah lembut dalam tutur kata, Istiqomah, teguh dalam keyakinan, Bersih diri, pakaian dan lingkungan. 16) Membiasakan mengucap kalimat-kalimat thayyibah. 17) Membiasakan melaksanakan puasa sunat seperti puasa Senin dan Kamis. 19) Melaksanakan pesantren kilat setiap
Bulan Ramadhan. 20) Menyelenggarakan PHBI, PHBN dan bakti sosial kemasyarakatan. ${ }^{19}$

Ada berapa hal nilai mendasar yang ada pada Madrasah Ibtidaiyah Al-Barokah An-Nur Ajung Jember yakni "Berakhlakul Karimah, Berprestasi, Disiplin dan Berbudaya Lingkungan". ${ }^{20}$ Penanaman Nilai Akblak (Berakblakul Karimah)

Permasalahan dunia saat ini yang banyak mendapat sorotan adalah masalah karakter peseta didik yang tercermin dalam bentuk perilaku. Banyaknya kasus kekerasan, perkelahian, tawuran, bahkan pelecehan seksual menyebabkan dunia pendidikan kehilangan jati diri. Penanaman nilai-nilai akhlak menjadi salah satu alternatif untuk menanamkan akhlakul karimah

19 Dokumentasi MI Al-Barokah AnNur Ajung Jember

20 Tartimatus Sholehah, Wawancara 17 Maret 2019 


\section{Luluk Sultoniyah, Ahmad Royani}

kepada peserta didik sehingga peserta didik mampu membentengi dirinya dari perbuatan tercela. ${ }^{21}$

Penaman nilai akhlak sejak dini merupakan hal penting untuk tumbuh kembang anak ketika menginjak dewasa. Betapa mirisnya wajah Indonesia yang hampir tiap hari disajikan televisi melalui siaran berita, seperti kasus pemerkosaan, tawuran, dan tindakan-tindakan kriminal yang seringkali menyebabkan jatuhnya korban, baik itu korban luka-luka hingga berujung kematian. Yang membuat lebih miris dari semua itu adalah usia para pelaku yang masih berstatus pelajar. Bahkan banyak di antara mereka masih duduk di bangku Sekolah Dasar. Terbesit banyak pertanyaan dalam benak kita, "Ada apa dengan anak bangsa ini?’" Marilah kita sebagai orang tua dan guru yang hakikatnya sama-sama berperan sebagai pendidik untuk merenungkan sejenak masalah ini

\footnotetext{
21 Fita Rohmatin, Wawancara 17 Maret 2019
}

hingga akhirnya tumbuh kepedulian tuk merubah wajah anak negeri. ${ }^{22}$ Dalam kutipan wawancara Tartimatus Sholehah mejelaskan

"Penanaman akhlak yang baik perlu di ajarkan sejak sedini mungkin, apabila seseorang telah memiliki akhlak yang baik, maka ia dapat menjaga segala ucapan dan perilakunya kepada siapapun. Maka di sinilah peran orang tua sebagai madrasah pertama untuk anak-anaknya, orangtua bertanggung jawab untuk mendidik akhlak anak agar menjadi pribadi yang soleh solehah, selain itu tanggung jawab orangtua untuk mendidik tentang pengetahuan anak. Oleh sebabnya MI ini lebih menegedepankan penanaman nilai-nilai akhlak sejak dini agar siswa bisa bermanfaat untuk masyarakat" ${ }^{\prime 23}$

Akhlak merupakan bagian yang sangat urgen dalam proses pendidikan dalam rangka membentuk manusia yang berakhlak mulia. Melalui pendidikan akhlak, manusia semakin tahu dan mengerti akan

\footnotetext{
22 Tartimatus Sholehah, Wawancara 17 Maret 2019

23 Tartimatus Sholehah, Wawancara 17 Maret 2019
} 
kedudukan dan tugasnya sebagai hamba dan khalifah di muka bumi, dan bisa mewujudkan masyarakat yang harmonis yang memerlukan kaidah-kaidah yang bersifat universal yang bersumber pada ilahi dan kemanusiaan. Dengan kata lain, kaidah-kaidah tersebut harus sesuai dengan tuntutan zaman yang ada dan sesuai dengan kaidah agama. Di sinilah letak urgensi akhlak dalam pendidikan, yaitu dalam merumuskan pendidikan agar senantiasa dalam bingkai yang benar dan berorientasi pada yang lebih baik.

Bentuk-bentuk penanaman nilai akhlaqul karimah sendiri di AlBarokah An-Nur Ajung Jember mencakup, 1) akhlak terhadap Allah SWT, 2)akhlak terhadap sesama manusia dan 3) akhlak terhadap alam. Sedangkan metode yang digunakan untuk penanaman akhlaqul karimah, antara lain : metode uswah atau keteladanan, metode hiwar atau percakapan, metode qishos atau cerita, metode amstal atau perumpamaan, metode pembiasaan, metode ibrah, metode janji dan ancaman. Dalam pengguaan metode sendiri guru menyesuaikan dengan kebutuhan, bisa dalam proses belajar mengajar dan juga diluar pembelajaran. ${ }^{24}$

Akhlak merupakan bagian yang sangat urgen dalam proses pendidikan dalam rangka membentuk manusia yang berakhlak mulia. Melalui pendidikan akhlak, manusia semakin tahu dan mengerti akan kedu-dukan dan tugasnya sebagai hamba dan khalifah di muka bumi, dan bisa mewujudkan masyarakat yang harmonis yang memerlukan kaidah-kaidah yang bersifat universal yang bersumber pada ilahi dan kemanusiaan. Dengan kata lain, kaidah-kaidah tersebut harus sesuai

\footnotetext{
${ }^{24}$ Tartimatus Sholehah, Wawancara 17 Maret 2019
} 


\section{Luluk Sultoniyah, Ahmad Royani}

dengan tuntutan zaman yang ada dan sesuai dengan kaidah agama. Di sinilah letak urgensi akhlak dalam pendidikan, yaitu dalam merumuskan pendidikan agar senantiasa dalam bingkai yang benar dan berorientasi pada yang lebih baik.

\section{Nilai Berpretasi}

Keunggulan prestasi Madrasah Ibtidaiyah Al-Barokah AnNur Ajung Jember selain aspek diatas juga menekankan pada prestasi akademik dalam proses belajarmengajar. Keberadaan madrasah sebagai lembaga pendidikan formal di Indonesia sesuai dengan UU No. 20 tahun 2003 tentang "Sistem Pendidikan Nasional" memiliki peranan strategis dalam mengembangkan Sumber daya Manusia (SDM), karena lulusan madrasah memberikan kontribusi bagi pembangunan nasional. Untuk itu, peran strategis madrasah perlu semakin ditingkatkan untuk merespon berbagai isu pendidikan nasional, baik yang terkait dengan otonomi madrasah, peningkatan mutu, akuntabilitas dan masalah guru.

Madrasah merupakan sekolah umum berciri khas Islam. Ciri khas Islam yang dimaksud adalah terdapatnya mata pelajaran Aqidah Akhlak, Al-Quran Hadits, Fiqih, Sejarah Kebudayaan Islam dan Bahasa Arab yang membedakannya dengan sekolah.

Dalam konteks penguatan prestasi di Madrasah Ibtidaiyah AlBarokah An-Nur Ajung Jember yang mencerminkan budaya relegius adalah target madrasah mulai dari kelas satu higga kelas enam nanti siswa bisa hafal satu Juz Al-Qur'an. Sebagaimana yang diungkapkan oleh kepala madrasah

"salah satu keunggulan prestasi dalam madrasah ini adalah diwajibkanya siswa dari kelas satu hingga kelas enam untuk bisa menghafal al-qur'an, tetapi yang paling membanggakan dalam hal ini adalah banyak diatara siswa sisiwi yang telah hafal lebih dari satu juz. Hal itu tidak terlepas 
Vol. 12, No. 1, April 2019

p-ISSN:2086 -0749

e-ISSN:2654-4784

dari motivasi dan juga dorongan dewan guru yang mendidik. ${ }^{25}$

\section{Disiplin}

Menjadi seorang yang sukses tidaklah cukup hanya memiliki nilai akademis yang baik.Untuk menjadi seseorang yang sukses dibutuhkan juga kegigihan dan kedisiplinan. Pentingnya kedisiplinan bisa kita lihat dari Negara-negara maju seperti contohnya Negara Jepang. Jepang merupakan salah satu Negara di Asia yang cukup maju. Salah satu kunci rahasia jepang untuk memajukan negaranya ialah dengan cara menumbuhkan karakter disiplin pada diri setiap warga negaranya.

Di Indonesia masalah kedisiplinan ini masih belum bisa teratasi. Lihat saja masih banyak sekali orang Indonesia yang terlambat datang ke sekolah, kampus bahkan

25 Tartimatus Sholehah, Wawancara 17 Maret 2019 ke kantor. Padahal ketika seseorang terlambat, hal tersebut dapat mengganggu produktivitasnya dan juga dapat mengganggu orang lain.

Pentingnya sebuah budaya disiplin juga diutarakan oleh kepala sekolah Madrasah Ibtidaiyah AlBarokah An-Nur Ajung Jember yakni Ibu Tartimatus Sholehah, beliau Mengatakan:

"Sangat penting.Karena peserta didik terlatih untuk belajar tepat waktu, istirahat tepat waktu dan pulang tepat waktu. Sehingga disiplin ini juga sangat berpengaruh terhadap kinerja kami di sekolah dan berpengaruh terhadap proses pembelajaran"26

Hal senada pun juga diutarakan oleh Ibu Ni'matul Ittihad yang mengajar mata pelajaran keaswajaan."Penting banget, karena kita harus punya

\footnotetext{
${ }^{26}$ Tartimatus Sholehah, Wawancara 17 Maret 2019
} 


\section{Luluk Sultoniyah, Ahmad Royani}

manajemen waktu, kalau kita tidak disiplin semua jadwal akan berantakan"27 Sementara itu Ibu Choirotul Hazanah selaku wakil kepala sekolah bidang kurikulum dan juga mengajar bahasa inggris mengatakan "Penting banget karena tanpa kedisiplinan akan berantakan",28

Masih dalam kaitan pentingnya budaya disiplin. Ibu Puput Siska Wardani yang menjabat guru bimbingan konseling mengatakan bahwa, "Penting banget, apa lagi untuk anak sekolah karena tanpa peraturan mereka bisa melakukan sesuatu sesuka hatinya, mereka tidak tahu mana yang baik dan mana yang benar". ${ }^{29}$ Sementara itu Bapak Muhammad Imron Rosidi menambahkan bahwa, "Sangat penting ya karena sekolah itu lembaga pen-

27 Ni'matul Ittihad, wawancara 17 Maret 2019

${ }^{28}$ Choirotul Hazanah, wawancara 18 Maret 2019

${ }^{29}$ Puput Siska Wardani, wawancara 19 Maret 2019 didikan jadi mendidik anak untuk disiplin itu sangat penting." ${ }^{30}$

Keterangan di atas dapat penulis simpulkan bahwa, budaya disiplin itu penting diterapkan di madrasah karena madrasah sebagai sebuah lembaga pendidikan tugasnya tidak hanya membagi ilmu pengetahuan kepada peserta didik tetapi bagaimana sekolah itu dapat membentuk pribadi yang disiplin pada diri setiap anak. Lewat tata tertib peraturan madrasah peserta didik akan diajarkan mana yang boleh dilakukan dan mana yang tidak boleh dilakukan dan menciptkan suasana lingkungan sekolah yang nyaman.

\section{Berbudaya Lingkungan}

Keteladanan merupakan salah satu unsur penting dalam pembentukan budaya bersih. Karena biasanya anak-anak akan mudah mengikuti dan mencontoh orang yang lebih dewasa darinya.

30 Muhammad Imron Rosidi, wawancara 17 Maret 2019 
Hasil wawancara peneliti dengan Kepala Al-Barokah An-Nur Ajung Jember, keteladanan yang beliau ajarkan yaitu dengan: Membersihkan sendiri area yang kotor. Apabila sedang berjalan dengan anak-anak dan melihat ada sampah yang jaraknya dekat, maka harus segera diambil dan dibuang pada tempatnya. Tapi jika banyak, maka perlu dibersihkan bareng bareng. Penanaman nilai-nilai bahwa apa yang mereka tinggali, tempati, yang menjadi tanggung jawab mereka, mereka harus perhatikan kebersihannya. ${ }^{31}$

Sedangkan menurut hasil wawancara dengan Choirotul Hazanah, beliau menyatakan bahwa "terkadang anak-anak itu tidak hanya mendengarkan kata-kata dari gurunya, akan tetapi mereka juga perlu bukti berupa tindakan dari seorang guru. Seperti pun-

31 Tartimatus Sholehah, Wawancara 17 Maret 2019 gut sampah dijalan, mereka seringkali tidak peka maka kita perlu ajarkan. Karena memang dari pimpinan mencontohkannya seperti itu. ${ }^{32}$

Dari hasil wawancara dengan Abdul Gafur, beliau menyatakan bahwa

"praktek adalah hal yang lebih menyentuh ke anak. Dengan cara gurunya memberikan contoh baik dengan berpakaian bersih dan tidak buang sampah sembarangan. ${ }^{33}$

Hasil wawancara peneliti dengan Cahyo Irwanto, beliau menyatakan bahwa

"cara kepala madrasah dalam memberikan contoh teladan bagi para guru, karyawan dan santri dengan cara "diberi pengarahan, di kontrol, dan ditindak. Biasanya kepala madrasah memberikan arahan pada saat rapat guru dengan selalu mengingatkan tentang hal kebersihan.

\footnotetext{
32 Choirotul Hazanah, S.Pd, $W a$ wancara 17 Maret 2019

33 Abdu Gafur, Wawancara 17 Maret 2019
} 


\section{Luluk Sultoniyah, Ahmad Royani}

Melakukan pengawasan dan pengontrolan oleh guru yang bersangkutan, seperti guru piket dan wali kelas terhadap kegiatan piket dan kegiatan kebersihan lainnya. Terakhir adalah menindak bagi para pelanggar kebersihan, dengan pemberian hukuman yang sesuai. Kepala madrasah adalah orang yang selalu memberikan contoh teladan bagi para guru, karyawan dan siswa.$^{34}$

Dari pimpinan inilah terdapat kekuatan visi, tekad yang kuat dan perhatian lebih terhadap kebersihan dan dijalankan selama bertahuntahun, sehingga berimbas kepada pimpinan-pimpinan di level keduanya. Strategi pertama yaitu adanya keinginan yang kuat bapak pimpinan secara real, dan yang kedua adalah keteladanan dari pimpinan-pimpinan dan yang ketiga lebih kepada hal-hal yang bersifat teknis seperti pembuatan SOP, tata tertib dan lain-lain. ${ }^{35}$

Keteladanan dan konsistensi dari pimpinan, kepala madrasah dan

34 Cahyo Irwanto, Wawancara 17 Maret 2019

35 Tartimatus Sholehah, Wawancara 17 Maret 2019 para guru ini yang memberikan pengaruh besar terhadap santri dalam upaya pembentukan budaya dan lingkungan bersih di MI AlBarokah An-Nur Ajung Jember. Keteladanan bapak pimpinan, kepala madasah dan guru yang memberikan teladan degan praktek langsung dalam kehidupan seharihari. Konsistensi bapak pimpinan terhadap kebersihan yang dilakukan secara terus menerus selama bertahun-tahun. Sehingga baik warga madrasah maupun pesatren dapat terbiasa dengan hidup bersih dan senantiasa menjaga kebersihan lingkungan dan kebersihan dirinya sendiri.

\section{Simpulan}

Pengembangan budaya religius pada perserta didik di MI Al-Barokah An-Nur Ajung Jember dilakukan dengan menanamkan perilaku atau tatakrama yang tersistematis dalam pengamalan agamanya masing-masing sehingga terbentuk kepribadian, karakter, sikap 
Vol. 12, No. 1, April 2019

p-ISSN:2086 -0749

e-ISSN:2654-4784

dan moralitas yang mulia, berjiwa luhur, dan bertanggung jawab, baik hubungannya dengan Allah swt, dengan sesama manusia maupun dengan lingkungan alam sekitar. Untuk itu nilai nilai yang dikembang di MI Al-Barokah An-Nur Ajung Jember yakni menekankan pada Akhlak, prestasi, disiplin dan berbudaya lingkungan.

\section{Daftar Pustaka}

Al-Mawardi, Abul Hasan, tt. Adab ad-dunya wa-addin, Kairo, Darr al ilm.

Arifin, Imron, Kepemimpinan Kyai : Studi Kasus Pesantren Tebu Ireng, (Malang: Kalimasada Press, 1996)

Asri Budiningsih. Pembelajaran Moral Berpijak pada Karakteristik Siswa dan Budayanya (Jakarta : Rineka Cipta, 2004)

Fajar, Malik. Holistika Pemikiran Pendidikan. (Bandung: Grafindo Persada,2005)

Husaini, Implementasi Budaya Religius di Pesantren, Madrasabe
Sekolah (Jogjakarta ; Pustaka Marwah. 2015)

Le Bon,Gustave, As-sunan anNafsiah Li tathownur al-Umam. Alih Bahasa; Abu Bakar Ibn Zuhayl, (Marocco : AlQurawiyien University, 1997)

Lickona, T. Character Matters: How To Help Our Childen Develop Goodjudgment, Integrity And Other Essential Virtues. (NewYork: Toughstone, 2004)

Madjid, Nurcholis, Masyarakat Religius,Membumikan nilai-nilai Islam dalam kebidupan Masyarakat. Jakarta: Paramadina, 1997)

Muhaimin, Paradigma Pendidikan Islam; Upaya Mengefektiflean Pendidikan Agama di sekolah. (Bandung, Remaja Rosdakarya, 2002)

Nasir, Mohammd, Pengembangan Pendidikan Karakter di Lembaga Pendidikan : Studi Multikasus di SMUN O4 dan SMU AlHidayah Malang, (Malang, Disertasi UNM, 2018)

Qomar, Mudjamil, Manajemen Pendidikan Islam, Strategi Baru 
Luluk Sultoniyah, Ahmad Royani

Pengelolaa Lembaga Pendidikan

Islam, Jakarta; Erlanggga, 2002)

Soekarto Indrafchrudi, Bagaimana

Mengakrabkan Sekolah dengan

Orangtua Murid dan

Masyarakat (Malang : IKIP

Malang, 1994)

Spradley, James P.. Metode Etnografi, terjemahan Misbah Zulfa, Tiara (Wacana, Yogjakarta, 1997)

Syam, Nur, Kepemimpinan Dalam Pengembangan Pondok Pesantren, dalam A. Halim et.al (ed.) Menegemen Pesantren, (Yogyakarta: Pustaka Pesantren, 2005)

Taufiq Hasyim, Budaya Relegius di lembaga Pendidikan Islam. (Bandung: Cita Pustaka Media, 2008)

Tim Diknas RI, Undang-undang nomor 20 tahun 2003 tentang Sisdiknas, (Jakarta, Pustaka Ofsett, 2003) 